\title{
A PUBLIC HEALTH APPROACH TO ENVIRONMENTAL AND OCCUPATIONAL HEALTH PROBLEMS IN DEVELOPING COUNTRIES
}

HÜLYA GÜL AND ZAHIDE CEREN ATLI

\section{Abstract}

The struggle to preserve and improve human and environmental health is meaningful and valuable. The role of public health scientists is to assemble and analyse evidence, leading, if possible, to proof of the health effects of environmental and occupational exposure. At the same time, it is the duty of the political superstructure to replace dangerous agents with substances that are safer, if possible eliminating all health risks entirely. Ideally, it is in this context that epidemiological research of environmental and occupational health problems should be conducted.

The discipline of public health is to investigate, comprehend and, as far as is possible, explain fully the causes, mechanisms and consequences of such hazards, and to develop and implement solutions such as preventive programmes, political initiatives and advocacy. The pursuit of sustainable development requires the construction of necessary social bodies and administrative mechanisms. Policies and academic studies that facilitate minimal environmental damage with maximum efficiency are required.

This chapter describes ways by which workplace and environmental health epidemiology can be used to improve public health and create a more habitable world for future generations. The chapter has a particular focus on Turkey, with a limited discussion of these issues in other developing countries. 


\section{Introduction}

Despite great scientific and technological advancement, many factors have created serious health problems in low-income, 'developing' countries. Industrialisation, irregular urbanisation and migration are associated with material and psychological distress, including from unemployment and income inequality. This process has been accelerated by the relocation of many polluting industries to less-developed countries, where labour is cheaper, regulation weaker and exploitation more systematic and ruthless.

The characterisation and prioritisation of environmental health problems and their causes through epidemiological and scientific research is needed to guide and advance sustainability. Sustainable development requires social and administrative mechanisms, including regulated policies that reduce environmental harm.

Although the 21st century is regarded as an era of significant scientific and technological development, it will also be recalled as a time scarred by increasing environmental degradation, natural disasters, industrial accidents and climate change (Dixon et al., 2009; Balbus et al., 2013; McMichael, 2013). Insufficient attention is given to the environmental and social pressures that permeate our living systems.

Many factors influence human and environmental health. Humans depend on their environments in every facet of their lives and are vulnerable to a myriad of physical, chemical, psychosocial, biologic, ergonomic and other factors that are either directly environmental or related to the environment. In developed countries, the burden of disease of many classical occupational health problems has been greatly reduced, such as lead poisoning and pneumoconiosis. But these gains are partly offset by newer problems, such as repetitive strain disorders, childhood cancers, multiple chemical sensitivity syndrome and sick building syndrome (McMichael and Butler, 2006; Gül, 2011).

Epidemiological science provides a logical approach to evaluate diseases and their causes, and thus to promote their prevention. Epidemiology can also be used to investigate the efficacy of existing or newly developed health initiatives.

In this chapter, stress is placed on the need to create healthy workplaces both for people and for a healthier planet. Harmful working conditions and practices will be discussed, focusing on environmental conditions and their context in developing countries. 


\section{Environmental Determinants}

Ecological degradation, pollution, climate change, rapid technological development, rapid population growth, poverty, globalisation and economic crises all affect health (Butler and Weinstein, 2011; Bowen et al., 2012; Kjellstrom and McMichael, 2013). Contemporary public health recognises that humans are not solely biological creatures, but exist within a social and environmental milieu. Public health provides a multidisciplinary means to improve knowledge, competencies and behaviours that protect and enhance human well-being. Public health advocates the cost-effectiveness of studies that aim to prevent diseases and to promote health, rather than their treatment, together with causal enquiry and the development of integrated approaches, including political intervention and advocacy (Butler and McMichael, 2010; Hanlon et al., 2012). Pollution to air, water, food and soil, whether caused by climate change, industry, traffic or human waste, can have direct and indirect unwanted health consequences (Capon and Rissel, 2010; Kjellstrom and McMichael, 2013). Disease causation has fixed and modifiable factors, varying by age, gender, location, workplace, social class, etc. Adverse environmental exposures often begin prenatally. The elderly, children and those with chronic diseases are especially vulnerable to environmental threats. Environmental pollution directly causes some diseases, aggravates others and, in some cases, accelerates their propagation.

Although, in developed countries, some forms of environmental pollution have declined, this is not the case in most developing nations. Furthermore, some kinds of environmental pollution, such as climate change, are not only geographically ubiquitous but also affect all social and economic strata, though at this stage to varying degrees. But some diseases can be prevented and even eradicated if their environmental causes can be removed. Modifiable factors include lifestyle choices (e.g. smoking) and other social habits. Over longer periods, some socio-economic, cultural and environmental conditions can also be altered.

Many diseases and social problems aggravated by climate change are preventable, if we take efficient measures (Huang et al., 2011; McMichael and Lindgren, 2011; Hanlon et al., 2012). However, unaddressed, climate change may prove the worst environmental catastrophe of our time; as such, it should direct attention towards the deterioration of the Earth's ecological balance.

Although the cost of climate change to the global economy is an important though disputed subject, its direct health effects are increasingly understood. Climate change is manifest through alterations to temperature, precipitation, humidity, clouds, wind, air pressure, fog and sea level. Health effects include 
increasing vector-borne diseases and worsened food and nutritional security. Increased cardiovascular and respiratory diseases due to air pollution interacting with heat waves from climate change are also likely.

The causes of human-made climate change include rising levels of carbon dioxide and other greenhouse gases, especially due to burning of fossil fuels. At the moment, combustion of fuels such as coal and oil are widely viewed as vital for ongoing industrial development, though this is challenged increasingly by the environmental movement. In Turkey, greenhouse gas emissions arise from the energy sector ( 71 per cent), industrial ( 13 per cent), waste ( 9 per cent) and agriculture (7 per cent) (TÜIK, 2013a). One study found a deterioration in lung function, measured by spirometry, for people living within the vicinity of a coal-fired thermal power plant in Kutahya (Karavuş et al., 2002). This is consistent with many other studies that show impaired respiratory health in association with coal particles.

The frequency and severity of diseases such as cancer are also related to many forms of environmental pollution (IARC, 2012). Cancer is the second leading cause of death (after cardiovascular disease) in both developed and developing countries. This pattern also applies in Turkey. In 2012, systemic circulatory diseases caused 37.9 per cent of deaths, followed by malignant neoplasm (21.1 per cent) and respiratory diseases (9.7 per cent) (see Tables 5.1 and 5.2) (TüíK, 2013b).

Table 5.1 Subgroups of cancer, by year in Turkey (per cent).

\begin{tabular}{|c|c|c|c|}
\hline Diseases/year & $\begin{array}{r}2010 \\
(\%)\end{array}$ & $\begin{array}{r}2011 \\
(\%)\end{array}$ & $\begin{array}{r}2012 \\
(\%)\end{array}$ \\
\hline Total & 100 & 100 & 100 \\
\hline Disease of the circulatory system & 39.6 & 38.8 & 37.9 \\
\hline Malignant neoplasms & 21.3 & 21.1 & 21.1 \\
\hline Disease of the respiratory system & 8.3 & 10.1 & 9.7 \\
\hline Endocrine, nutritional and metabolic diseases & 6.4 & 6.3 & 6.0 \\
\hline Diseases of the nervous system and the sense organs & 3.7 & 3.7 & 4.3 \\
\hline External causes of injury and poisoning & 4.4 & 4.1 & 4.1 \\
\hline $\begin{array}{l}\text { Other (infectious and parasitic diseases, mental and behavioural } \\
\text { disorders, diseases of the musculoskeletal system/connective } \\
\text { tissue, etc.) }\end{array}$ & 16.3 & 15.9 & 16.9 \\
\hline
\end{tabular}

Source: TÜIK, 2013b. 
Table 5.2 Distribution (per cent) of causes of death by year in Turkey.

\begin{tabular}{|l|r|r|r|}
\hline Subgroup/year & $\begin{array}{r}\mathbf{2 0 1 0} \\
\mathbf{( \% )}\end{array}$ & $\begin{array}{r}\mathbf{2 0 1 1} \\
\mathbf{( \% )}\end{array}$ & $\begin{array}{r}\mathbf{2 0 1 2} \\
\mathbf{( \% )}\end{array}$ \\
\hline Larynx and trachea/bronchus/lung & 31.2 & 31.0 & 31.6 \\
\hline Stomach & 8.8 & 8.8 & 8.4 \\
\hline Lymph/haematopoietic tissue & 8.5 & 8.3 & 8.0 \\
\hline Colon & 6.5 & 6.7 & 6.7 \\
\hline Pancreas & 5.2 & 5.4 & 5.3 \\
\hline Other & 39.8 & 39.9 & 39.9 \\
\hline
\end{tabular}

Source: TÜiK, 2013b.

Environmental epidemiological studies range from analysis of social data to individualised on-site data collection (Schenker, 2007; Liu et al., 2012). These can reveal relationships between environmental factors and health outcomes of value to policymakers. Environmental epidemiology also investigates workers' complaints, disease clusters and other unexpected increases in their incidence.

Scientists have ethical and professional responsibilities to research suspected health effects in a timely fashion and to disseminate their findings. Often, however, these actions are limited by vested interests, such as corporations who profit from pollution, as recently noted by Margaret Chan in a WHO meeting (2013).

So-called 'ecological' studies (which, confusingly, have nothing to do with natural ecosystems) are used in environmental epidemiology to analyse grouplevel spatial and temporal disease distribution. Since these studies rely on aggregated data, it is impossible to correlate exposure with individual health status. The 'ecological fallacy' is the false inference of individual causation from such studies, and is sometimes alleged to discredit all such studies. However, without additional approaches, including individualised data if possible, the ecological fallacy can neither be proven nor disproven. That is, the relationships found in ecological studies may actually be valid (Ojha et al., 2011; Pleil et al., 2012).

The dose-response relationship is central to epidemiological evaluation. Epidemiologists seek to determine the critical level at which effects are detectable and to explore if the effect increases with dose. Many dose-response relationships are based on animal studies. But the measurement of cumulative human exposure is very difficult, and relationship to chronic diseases even more so; such measurements are further complicated by interactions among these exposures. Chronic, low-level environmental exposure can cause chronic damage. However, the determination of such risks is also challenging. 
Although epidemiological work reliant on occupational and environmental toxicology is helpful, multidirectional research is necessary to explore hypotheses about factor-consequence relationships.

Some massive sources of industrial pollution cause relatively distinct public health effects. For example a study found the increased incidence of neural tube defects observed in major hospitals in the Black Sea region of Turkey (Mocan et al., 1992). The most plausible hypothesis for this is radiation from the huge 1986 disaster at the Chernobyl nuclear power plant in Turkey's Black Sea neighbour, Ukraine. This was caused by inadequate regulation and a poor safety culture. This affected people from the Republics of Ukraine and Belarus, as well as in Russia and parts of Europe, especially in Scandinavia. By 2005, approximately 5,000-6,000 cases of thyroid cancer had been diagnosed among people who were children or adolescents at the time of the accident, then living in Belarus, the Russian Federation and Ukraine (Bennett et al., 2006;UNSCEAR, 2011). Another notorious industrial accident, with substantial health effects, was the massive methyl isocyanate leakage in Bhopal, India, in 1984. This world's worst industrial disaster raised questions about the implications of the transfer of potentially hazardous technology to developing countries (Varma and Varma, 2005; Eckerman, 2011).

Environmental exposure to asbestos is an important public health issue in Turkey, and the use and trade of asbestos has been forbidden since 31 December 2010. Such exposure is mostly in rural areas, in contrast to the pattern in most developed countries. The number of people estimated to have been exposed to asbestos in rural areas of Turkey in 2012 is approximately one million. The risk of pleural mesothelioma and lung cancer was found to be 799 and 44 times higher, respectively, in women exposed to asbestos in rural areas than in those from the general population (Metintas et al., 2012; Ministry of Health, Republic of Turkey, 2012).

\section{Occupational Determinants}

Occupational health, which originated in the Industrial Revolution, is still very important, especially in developing countries. It is multidimensional, encompassing medicine, law, engineering and social sciences. Work has physical, mental, moral, chemical, social and economic aspects (Gül, 2012; Marmot et al., 2012). Occupational health protection requires recognition and, if possible, integrated regulation of these factors. The discipline of occupational health aims to prevent work accidents, injuries and diseases and to advocate long-term health protection. However, especially where employers 
and unions (if they exist) cooperate, workers can provide a valuable means for epidemiological research and insight, because they constitute a stable social group, some of whose environmental exposures can be quantified.

However, health damage due to industrialisation can be difficult to estimate, due to many interacting factors. For example, in Turkey, Dilovası and the wider, heavily industrialised province of Kocaeli is one of the most polluted provinces in Turkey. In addition, the country's largest highway passes through the city. Fifteen per cent of Turkey's accumulative manufacturing industry is based in Kocaeli. A recent study, though not age adjusted, found that the rate of cancerrelated death in Dilovasi (33 per cent) was 2.6- and 2.7-fold more than that of the rest of Turkey and the world, respectively (Hamzaoğlu et al., 2011).

Health risks arise at many stages of a production process, from access to the raw material to the finished product. Different forms of business bear specific risks. However, workers are relatively healthy individuals selected from the main population, with an expected probability of death lower than the general population, a phenomenon coined by Tony McMichael as the 'healthy worker effect' (McMichael, 1976).

Many occupational factors are suspected as having a role in disease aetiology, including asbestos, benzene, coal dust, heavy metals, pesticides, aromatic amines, silicon dioxide, chrome, vinyl chloride and radiation. Silicosis had been an important occupational health disease in Turkey because of the sandblasting of denim jeans using silica (Ozturk et al., 2012). Sandblasting work was prohibited in 2009 by the Health Ministry of the Republic of Turkey. But, by then, approximately 600 silicosis cases had been diagnosed in the textile sector, of which 54 had died. But other estimates suggested the real number of cases was nearer 5,000. Another study found an increased incidence of secondary pneumothorax in acute and accelerated forms of silicosis due to denim sandblasting (Kaynar et al., 2012). According to the results of another study, radiological evidence of silicosis (International Labour Organization (ILO) score $1 / 0$ or higher) was present in 53 per cent of 145 sandblasting workers with interpretable chest radiographs (Akgun et al., 2008). Dental prosthetic technicians in Turkey also experience high rates of occupational silicosis, perhaps as high as 10 per cent (Cimrin et al., 2009).

The investigation of environmental exposures will remain challenging. There is significant variation between exposure levels determined by measurements made in the external environment versus exposure levels determined at the point of contact between the environment, the individual and in the human body. This variation can be the result of idiosyncratic variables such as personal lifestyles, physiological characteristics and the time and place of exposure. Another approach is to measure exposure levels from tissue or blood samples 
taken from humans or animals. In some cases, the impact of industrial pollution cannot be determined by observing acute symptoms, but can be inferred from accumulated effects. However, in such cases, persuading the public and regulators of the causal relationships can be difficult. However, these uncertainties do not mean we dismiss the possibility of risk; epidemiological investigation must continue.

Our understanding and motivation to research these issues has been influenced by Tony McMichael, who taught one of the authors of this chapter (HG) at a course on the epidemiology of cancer, ran by the International Agency for Research on Cancer (IARC) and the World Health Organization, in Lyon, France, in July 2005. HG later encountered Tony at several meetings, including some hosted by the International Society for Environmental Epidemiology (ISEE), of which she became a member in 2007. In fact, it was through ISEE that we first heard of the opportunity to contribute to this book.

\section{Conclusion}

A major purpose of this new public health is to control environmental pollution, including occupational exposure, and to protect human health. The socio-economic status of people affects their health and quality of life greatly, so the prevalence and severity of cancer, diabetes, obesity, etc, has increased rapidly in recent years in the developing countries. Climate change, which affects both environmental and socio-economic considerations for all states, plays an increasingly decisive role in sustainable development efforts, both globally and locally. To mitigate climate change and its impacts, states must take the required measures at national as well as international levels, and follow through on their application.

Academics conduct scientific research in order to determine causes of environmental deterioration and exposure. Epidemiological studies analysing the effects of the environment on human health, on an environmental and occupational basis, are a critical aspect of such efforts. Taking into consideration the results of the research carried out for the prevention of risk and the sustainability of measures, the required social and management mechanisms must be created by legislators, and the existing measures must be enforced.

Egalitarian public health policies must be applied with due care for the general public to achieve a fulfilling and healthy life in a clean and safe environment. Environmental and occupational conditions must be investigated from a multidisciplinary perspective, and their impact on public health must be evaluated from all dimensions. 


\section{References}

Akgun, M., Araz, O., Akkurt, I., Eroglu, A., Alper, F., Saglam, L., et al. 2008. An epidemic of silicosis among former denim sandblasters. European Respiratory Journal 32, 1295-303.

Balbus, J.M., Boxall, A.B., Fenske, R.A., McKone, T.E. \& Zeise, L. 2013. Implications of global climate change for the assessment and management of human health risks of chemicals in the natural environment. Environmental Toxicology \& Chemistry 32, 62-78.

Bennett, B., Repacholi, M. \& Carr, Z. (eds) 2006. Health Effects of the Chernobyl Accident and Special Health Care Programmes: Report of the UN Chernobyl Forum Health Expert Group. World Health Organization,Geneva, Switzerland. Available at www.who.int/ionizing_radiation/chernobyl/who_ chernobyl_report_2006.pdf, accessed 14 February 2015.

Bowen, K., Friel, S., Ebi, K., Butler, C.D., Miller, F. \& McMichael, A.J. 2012. Governing for a healthy population: an exploration of how decision-making will determine our global health in a changing climate. International Journal of Environmental Research and Public Health 9, 55-72.

Butler, C.D. \& McMichael, A.J. 2010. Population health: where demography, environment and equity converge. Journal of Public Health 32, 157-8.

Butler, C.D. \& Weinstein, P. 2011. Global ecology, global health, ecohealth. EcoHealth 8, 253-4.

Capon, A.G. \& Rissel, C.E. 2010. Chronic disease and climate change: understanding co-benefits and their policy implications. NSW Public Health Bulletin 21, 109-13.

Chan, M. 2013. Opening address at the 66th World Health Assembly. www.who.int/dg/speeches/2013/world_health_assembly_20130520/en/, accessed 14 February 2015.

Cimrin, A., Kömüs, N., Karaman, C. \& Tertemiz, K.C. 2009. Pneumoconiosis and work related health complaints in Turkish dental laboratory workers. Tüberküloz ve Toraks 57, 282-8.

Dixon, J.K., Hendrickson, K.C., Ercolano, E., Quackenbush, R. \& Dixon, J.P. 2009. The environmental health engagement profile: what people think and do about environmental health. Public Health Nursing 26, 460-73. 
Eckerman, I. 2011. Bhopal gas catastrophe 1984: causes and consequences. In: Nriagu, J.O. (ed.) Encyclopedia of Environmental Health. Elsevier, Burlington, Massachusetts, USA, 302-16.

Gül, H. 2011. Sick building syndrome from perspective of occupational and public health. In: Sabah, A. \& Al-Sulaiman, A.-W. (eds) Sick Building Syndrome in Public Buildings and Workplaces. Springer, USA, 89-104.

Gül, H. 2012. Mobbing at workplaces and the mental health effects on employees. In: Olisah, V. (ed.) Essential Notes in Psychiatry. InTech - Open Access Publisher, Croatia.

Hamzaoğlu, O., Etiler, N., Yavuz, C.I. \& Cağlayan, C. 2011. The causes of deaths in an industry-dense area: example of Dilovasi (Kocaeli). Turkish Journal of Medical Sciences 41, 369-75.

Hanlon, P., Carlisle, S., Hannah, M., Lyon, A. \& Reilly, D. 2012. A perspective on the future public health practitioner. Perspectives in Public Health 132, 235-39.

Huang, C., Vaneckova, P., Wang, X., FitzGerald, G., Guo, Y. \& Tong, S. 2011. Constraints and barriers to public health adaptation to climate change: a review of the literature. American Journal of Preventive Medicine 40, 183-90.

IARC. 2012. Review of Human Carcinogens (package of 6 volumes A,B,C,D,E,F). IARC Monographs on the Evaluation of Carcinogenic Risks to Humans,Lyon, France.

Karavuş, M., Aker, A., Cebeci, D., Tasdemir, M., Bayram, N. \& Çalı, Ş. 2002. Respiratory complaints and spirometric parameters of the villagers living around the Seyitomer coal-fired thermal power plant in Kutahya, Turkey. Ecotoxicology and Environmental Safety 52, 214-20.

Kaynar, H., Aydın, Y.A., Akgün, M., Türkyılmaz, A. \& Eroğlu, A. 2012. Pneumothorax in the cases with silicosis due to denim sandblasting. Turkish Journal of Thoracic and Cardiovascular Surgery 20, 291-4.

Kjellstrom, T. \& McMichael, A.J. 2013. Climate change threats to population health and well-being: the imperative of protective solutions that will last. Global Health Action 6, 1-9.

Liu, C.-Y., Maity, A., Lin, X., Wright, R. \& Christiani, D. 2012. Design and analysis issues in gene and environment studies. Environmental Health 11, 93 doi:10.1186/1476-069X-11-93. 
McMichael, A.J. 1976. Standardized mortality ratios and the 'healthy worker effect': scratching beneath the surface. Journal of Occupational Medicine $18,165-8$.

McMichael, A.J. 2013. Globalization, climate change and health. New England Journal of Medicine 368, 1335-43.

McMichael, A.J. \& Butler, C.D. 2006. Emerging health issues: the widening challenges for population health promotion. Health Promotion International $21,15-24$.

McMichael, A.J. \& Lindgren, E. 2011. Climate change: present and future risks to health, and necessary responses. Journal of Internal Medicine 270, 401-13.

Marmot, M., Allen, J., Bell, R., Bloomer, E. \& Goldblatt, P. 2012. WHO European review of social determinants of health and the health divide. The Lancet $380,1011-29$.

Metintas, S., Metintas, M., Ak, G. \& Kalyoncu, C. 2012. Environmental asbestos exposure in rural Turkey and risk of lung cancer. International Journal of Environmental Health Research 22, 468-79.

Ministry of Health. Republic of Turkey 2012. Strategic Plan for Asbestos Control in Turkey. kanser.gov.tr/Dosya/ar-ge/asbest.pdf, accessed 14 February 2015.

Mocan, H., Aydemir, V., Bozkaya, H., Mocan, M. \& Özbay, G. 1992. Incidence of neural tube defects (NTD) in Ankara, Turkey, prior to and after the Chernobyl disaster. Paediatric and Perinatal Epidemiology 6, 111-4.

Ojha, R.P., Offutt-Powell, T.N., Evans, E.L. \& Singh, K.P. 2011. Correlation coefficients in ecologic studies of environment and cancer. Archives of Environmental and Occupational Health 66, 241-4.

Ozturk, A., Cımrın, A.H., Tur, M. \& Guven, R. 2012. Prevalence of silicosis among employees in feldspat and quartz mills and associated factors with silicosis. Tüberküloz ve Toraks 60, 224-9.

Pleil, J.D., Sobus, J.R., Sheppard, P.R., Ridenour, G. \& Witten, M.L. 2012. Strategies for evaluating the environment-public health interaction of long-term latency disease: the quandary of the inconclusive case-control study Chemico-Biological Interactions 196, 68-78.

Schenker, M.B. 2007. Appendix: Biostatistics \& Epidemiology. In: Ladou, J. (ed.) Current Occupational \& Environmental Medicine (4th edition). McGraw Hill Medical,New York, USA, 789-813. 
TÜIK 2013a. Turkey greenhouse gas inventory 1990-2011 - annual report for submission under the Framework Convention on Climate Change. Ankara: Turkish Statistical Institute, No: 13482. www.turkstat.gov.tr/ PreHaberBultenleri.do?id=13482, accessed 14 February 2015.

TÜIKK 2013b. Causes of death statistics, 2010, 2011 and 2012. Turkish Statistical Institute, No 15847. Prime Ministry,Ankara, Republic of Turkey. www. turkstat.gov.tr/PreHaberBultenleri.do?id=15847, accessed 14 February 2015.

UNSCEAR 2011. Health effects due to radiation from the Chernobyl accident. United Nations Scientific Committee on the Effects of Atomic Radiation, Vol 2, Supplement No 46. United Nations Publication,New York, USA, 47-205.

Varma, R. \& Varma, D.Y. 2005. The Bhopal disaster of 1984. Bulletin of Science, Technology \& Society 25, 37-45. 
This text is taken from Health of People, Places And Planet:

Reflections based on Tony McMichael's four decades of contribution to epidemiological understanding, edited by Colin D. Butler, Jane Dixon and Anthony G. Capon, published 2015 by ANU Press, The Australian National University, Canberra, Australia. 